\title{
DINAMIKA MUSIM PENANGKAPAN IKAN CAKALANG DAN TONGKOL DI PERAIRAN PALABUHANRATU
}

\author{
Dynamics of Skipjack and Longtail Tuna Fishing Season in Palabuhanratu Waters
}

Oleh:

Tri Wiji Nurani ${ }^{*}$, Prihatin Ika Wahyuningrum ${ }^{1}$, Muhammad Iqbal ${ }^{2}$, Nurani Khoerunnisa ${ }^{3}$, Gilar Budi Pratama 3 , Elvanri Anggi Widianti³, Muhammad Fikri Kurniawan ${ }^{4}$

\footnotetext{
${ }_{1}$ Departemen Pemanfaatan Sumberdaya Perikanan, Fakultas Perikanan dan Ilmu Kelautan Institut Pertanian Bogor, triwiji@hotmail.com, piwahyuningrum@apps.ipb.ac.id

2 Departemen Ilmu dan Teknologi Kelautan, Fakultas Perikanan dan Ilmu Kelautan Institut Pertanian Bogor, muhammadiqbal@apps.ipb.ac.id

3 Program Studi Teknologi Perikanan Laut, Sekolah Pascasarjana Institut Pertanian Bogor, nurani_khoerunnisa@apps.ipb.ac.id, gilarbudi@apps.ipb.ac.id,elvanri_01@apps.ipb.ac.id

4Program Studi Teknologi dan Manajemen Perikanan Tangkap Institut Pertanian Bogor, fikkur21@gmail.com
}

* Korespondensi: triwiji@hotmail.com

Diterima: 16 Agustus 2021; Disetujui: 16 November 2021

\begin{abstract}
The monthly fluctuation of fish catch is closely related to the presence of fish or the fishing season. Information about the fishing season is important to improve the efficiency and effectiveness of fishing carried out by fishermen. Skipjack and longtail tuna are important catches landed by fishermen in Palabuhanratu fishing port, with fishing grounds in the waters around Palabuhanratu. This study aims to describe the dynamics of the catch and the effort to catch skipjack tuna and longtail tuna that land their fish in the Palabuhanratu fishing port and determine the fishing season. The data used is the Palabuhanratu fishing port fisheries statistical data for the 2015-2019 period. Data analysis used catch per unit effort (CPUE) analysis and moving average method. The results showed that the CPUE value of skipjack tuna fluctuates tends to increase by 0,009 tons per trip in 2016 and reaches the highest in 2017 which is around 3,068 tons per trip. The CPUE value of longtail tuna tends to increase from 0,021 tons per trip in 2015 to 0,266 tons per trip in 2019. The skipjack tuna fishing season in Palabuhanratu Waters occurs in March, July to November, while the longtail tuna fishing season occurs from July to November.
\end{abstract}

Keywords: Longtail tuna, fishing season index, moving average model, Palabuhanratu, skipjack tuna

\section{ABSTRAK}

Fluktuasi hasil tangkapan ikan secara bulanan erat kaitannya dengan keberadaan ikan atau musim penangkapan ikan. Informasi tentang musim penangkapan ikan, penting untuk meningkatkan efisiensi dan efektivitas penangkapan ikan yang dilakukan oleh nelayan. Ikan cakalang dan tongkol merupakan hasil tangkapan penting yang didaratkan oleh nelayan di PPN Palabuhanratu, dengan daerah penangkapan ikan di sekitar Perairan Palabuhanratu. Penelitian ini bertujuan untuk mendeskripsikan dinamika hasil tangkapan dan upaya penangkapan ikan cakalang dan tongkol yang berbasis di PPN Palabuhanratu serta menentukan musim penangkapannya. Data yang digunakan yaitu statistik perikanan PPN Palabuhanratu periode tahun 2015-2019. Analisis data menggunakan analisis catch per unit effort (CPUE) dan metode rata-rata bergerak. Hasil penelitian menunjukkan 
bahwa nilai CPUE alat penangkap ikan cakalang berfluktuasi cenderung meningkat yaitu sebesar 0,009 ton per trip pada tahun 2016 dan mencapai tertinggi pada tahun 2017 yaitu sekitar 3,068 ton per trip. Nilai CPUE alat penangkap ikan tongkol cenderung meningkat yaitu dari 0,021 ton per trip pada tahun 2015 menjadi 0,266 ton per trip pada tahun 2019. Musim penangkapan ikan cakalang di Perairan Palabuhanratu terjadi pada bulan Maret, Juli sampai dengan September, sedangkan musim penangkapan ikan tongkol terjadi pada bulan Juli sampai dengan September. Musim penangkapan ikan ini dapat menjadi acuan bagi nelayan dalam melakukan kegiatan operasi pengkapan ikannya.

Kata kunci: cakalang, indeks musim penangkapan ikan, model rata-rata bergerak, Palabuhanratu, tongkol

\section{PENDAHULUAN}

Ikan cakalang dan tongkol merupakan komoditas perikanan penting bagi Indonesia, dan dikelola secara tersendiri yaitu dalam pengelolaan perikanan tuna, cakalang, tongkol (TCT). Perairan Palabuhanratu yang tercakup dalam perairan Samudera Hindia memiliki potensi sumber daya ikan cakalang dan tongkol yang potensial, dengan produksi ikan cakalang pada tahun 2019 adalah 318,00 ton dan ikan tongkol pada tahun yang sama adalah 861,57 ton (PPN Palabuhanratu 2019).

Produksi ikan cakalang dan tongkol di Perairan Palabuhanratu pada periode lima tahun terakhir terlihat berfluktuasi yaitu berkisar antara 53,73 ton per tahun sampai dengan 318,00 ton per tahun untuk ikan cakalang, dan antara 35,222 ton per tahun sampai dengan 861,57 ton per tahun untuk ikan tongkol. Fluktuasi produksi ikan cakalang dan tongkol juga terjadi secara bulanan. Mujib et al. (2013) menyatakan bahwa persebaran ikan tongkol (Euthynnus sp.) di Perairan Palabuhanratu mengalami nilai puncak pada bulan-bulan tertentu saja. Fluktuasi produksi atau hasil tangkapan ikan dipengaruhi oleh berbagai faktor, diantaranya yaitu jumlah upaya atau trip penangkapan ikan yang dilakukan (Ahmad 2015; Situmorang et al. 2018; Ishak et al. 2020), dapat juga dipengaruhi oleh parameter-parameter oseanografis perairan seperti suhu permukaan laut dan kandungan klorofil-a (Simbolon 2009; Safruddin et al. 2014; Zulkhasyni 2015; Zainuddin et al. 2015; Nurani et al. 2015; Nurani et al. 2016; Wangi et al. 2019; Wiryawan et al. 2020).

Fluktuasi hasil tangkapan ikan secara bulanan erat kaitannya dengan keberadaan ikan atau musim penangkapan ikan. Ahmad (2015) menyatakan bahwa musim penangkapan ikan adalah kondisi dimana kegiatan penangkapan ikan dilakukan lebih intensif dibandingkan dengan periode lainnya dalam setahun, dengan kata lain bahwa stok sumber daya ikan pada saat tersebut sangat berlimpah melebihi kondisi normalnya. IOTC (2016) menyatakan bahwa pengkajian terkait dengan musim penangkapan ikan dapat digunakan untuk pengaturan waktu penangkapan ikan agar upaya penangkapan yang dilakukan oleh nelayan dapat lebih efektif dan efisien. Ketepatan musim penangkapan dapat membantu pengelola untuk melakukan tindakan pengelolaan di masa yang akan datang, seperti musim buka dan tutup. Dengan mengetahui tingkat tangkapan musiman, contohnya pada ikan cakalang dan tongkol ini maka efektivitas operasi penangkapan dapat ditingkatkan, sehingga biaya operasional dapat ditekan.

Ikan cakalang dan tongkol yang didaratkan di Pelabuhan Perikanan Nusantara (PPN) Palabuhanratu dihasilkan oleh nelayan dengan berbagai alat tangkap, diantaranya ikan cakalang dominan ditangkap menggunakan alat tangkap longline dan pancing tonda. Sementara ikan tongkol dominan ditangkap dengan menggunakan alat tangkap pancing ulur, payang, jaring rampus, dan bagan. Unit penangkapan ini tidak jauh berbeda dengan unit penangkapan ikan yang digunakan oleh nelayan untuk menangkap ikan pelagis di daerah lain, seperti di Perairan Laut Banda (Waileruny et al. 2014); Selat Makassar (Kantun et al. 2018), dan Perairan Kendari (Ishak et al. 2020).

Unit penangkapan ikan cakalang dan tongkol yang digunakan oleh nelayan di Perairan Palabuhanratu merupakan unit penangkapan skala kecil hingga sedang yang membutuhkan informasi terkait musim penangkapan ikan yang menjadi tujuan tangkapnya agar aktivitas penangkapan efisiensi dan efektif. Oleh karena itu penelitian ini perlu dilakukan. Penelitian ini bertujuan untuk mendeskripsikan produksi ikan cakalang dan tongkol yang didaratkan di PPN Palabuhanratu, dan menentukan musim 
penangkapannya. Pendekatan studi dilakukan dengan menganalisis data hasil tangkapan dan upaya penangkapan serta informasi terkait lainnya dari Statistik Perikanan PPN Palabuhanratu.

\section{METODE}

Pengambilan data penelitian dilakukan pada bulan Mei sampai Juli tahun 2021 di PPN Palabuhanratu. Penelitian ini fokus pada kapal-kapal penangkap ikan cakalang dan tongkol yang melakukan kegiatan penangkapan di Perairan Palabuhanratu dan mendaratkan ikan di PPN Palabuhanratu Kabupaten Sukabumi, Provinsi Jawa Barat (Gambar 1).

Data yang dikumpulkan pada penelitian adalah jumlah produksi ikan cakalang dan tongkol, serta upaya penangkapan ikan (trip) dari unit penangkapan ikan yang mendaratkan ikannya di PPN Palabuhanratu, selama periode lima tahun (2015-2019). Data jumlah produksi ikan cakalang dan tongkol, serta upaya penangkapan ikan diperoleh dari data statistik PPN Palabuhanratu.

Analisis data dilakukan dengan cara menghitung catch per unit effort (CPUE) dan menghitung indeks musim penangkapan (IMP) menggunakan metode rata-rata bergerak (moving average). Formula yang digunakan mengacu pada Nurdin \& Panggabean (2017), yaitu sebagai berikut.

\section{Analisis CPUE}

Analisis CPUE digunakan untuk mengestimasi produktivitas alat tangkap. Analisis CPUE dihitung berdasarkan perbandingan total hasil tangkapan (catch) dengan jumlah total upaya penangkapan (effort). Alat penangkapan ikan cakalang yang digunakan nelayan di Palabuhanratu yaitu pancing tonda dan longline, sedangkan alat penangkapan ikan tongkol yang digunakan yaitu payang, rampus, bagan, pancing ulur, purse seine, dan gillnet. Menurut Gulland (1982), CPUE dapat dihitung dengan formula sebagai berikut:

1) Data catch dan effort dibuat dalam bentuk tabel, lalu dihitung nilai CPUE pada setiap tahunnya

CPUE $=\frac{\text { Catch }}{\text { Effort }}$

dengan:

$\begin{array}{ll}\text { CPUE } & : \text { Hasil tangkapan per upaya penangkapan } \\ \text { (ton/trip) }\end{array}$

\section{2) Standardisasi Upaya Penangkapan}

Jika terdapat beberapa alat tangkap di suatu daerah, maka salah satunya digunakan sebagai standar dan alat tangkap lain distandardisasi terhadap alat tangkap tersebut. Standardisasi perlu dilakukan karena setiap alat tangkap memiliki ukuran kemampuan yang berbeda-beda. Standardisasi dilakukan dengan tahapan sebagai berikut.

a) Perhitungan Fishing Power Index (FPI)

$\mathrm{FPI}=\frac{\text { CPUE dst }}{\text { CPUEst }}$

dengan:

FPI : Fishing power index

CPUEdst : CPUE alat tangkap yang akan distandardisasi (ton/trip)

CPUEst : CPUE alat tangkap standar (ton/trip)

b) Perhitungan Upaya Standar

$F S=F P I \times F d s t$

dengan:

Fs : upaya penangkapan hasil standardisasi (trip)

Fdst : upaya penangkapan hasil yang akan distandardisasi (trip)

c) Analisis CPUE

Nilai CPUE dihitung kembali dengan nilai upaya penangkapan yang baru atau setelah distandardisasi, sedangkan nilai catch tetap.

CPUEs $=\frac{\text { Catch }}{\text { Effort }}$

dengan:

CPUEs : Hasil tangkapan per hasil standardisasi upaya penangkapan (ton/trip)

Catch : Hasil tangkapan dalam bulan ke-i (ton)

Effort : Upaya penangkapan hasil standardisasi dalam bulan ke-i (trip)

Jika nilai tren CPUE meningkat dari tahun ke tahun maka dapat dianggap bahwa sumber daya ikan di perairan tersebut relatif baik, yang secara tidak langsung usaha penangkapan ikan diduga masih menguntungkan. Sebaliknya apabila tren CPUE menurun maka diduga mulai terjadi gejala over fishing.

\section{Musim Penangkapan Ikan}

Berdasarkan Dajan (1983) yang dimodifikasi oleh Wiyono et al. (2006), langkah-langkah perhitungan musim penangkapan sebagai berikut:

a) Menyusun deret CPUE

CPUE $=n_{i}$ 
dengan:

i : $1,2,3, \ldots, n$

$\mathrm{n}_{\mathrm{i}}:$ urutan ke-i

b) Menyusun rata-rata bergerak CPUE selama 12 bulan (RG)

$R G i=\frac{1}{12}\left[\sum_{i=i-6}^{i+5} C P U E i\right]$

dengan:

RG : rata-rata bergerak 12 bulan urutan ke-i

CPUEi : CPUE urutan ke-i

i $\quad: 7,8, \ldots, \mathrm{n}-5$

c) Menyusun rata-rata bergerak CPUE terpusat (RGP):

$R G P i=\frac{1}{2}\left[\sum_{i=1}^{i=1} R G i\right]$

dengan:

RGPi : rata-rata bergerak CPUE terpusat ke-i

$\mathrm{RGi}$ : rata-rata bergerak 12 bulan urutan ke-i

I $: 7,8, \ldots, \mathrm{n}-5$

d) Menyusun rasio rata-rata tiap bulan (Rb):

$R b i=\frac{C P U E i}{R G P i}$

dengan:

$\mathrm{Rbi}$ : rasio rata-rata bulan urutan ke-i

CPUEi : CPUE urutan ke-i

RGP i: rata-rata bergerak CPUE terpusat urutan ke-i

e) Menyusun nilai rasio rata-rata dalam satu matriks berukuran $\mathrm{i} x \mathrm{j}$ yang disusun untuk setiap bulan, dimulai dari bulan Januari tahun 2015 sampai dengan bulan Desember tahun 2019.

f) Menghitung total rasio rata-rata bulanan (JRRBi)
$J R R B i=\sum_{i=1}^{12} R R B i$

dengan:

JRRBi : Jumlah rasio rata-rata bulanan

$\mathrm{RBBi} \quad$ : rata-rata Rbij untuk bulan ke-i

i $\quad: 1,2, \ldots ., 12$

g) Indeks musim penangkapan

Idealnya jumlah rasio rata-rata bulanan JRBB sama dengan 1200, namun karena banyak faktor sehingga nilai JRBB tidak selalu sama dengan 1200 . Oleh karena itu nilai rasio rata-rata bulanan harus dikoreksi dengan suatu nilai koreksi yang disebut dengan Faktor Koreksi (FK).

Rumus untuk memperoleh nilai Faktor Koreksi adalah:

$\mathrm{FK}=\frac{1200}{J R B B}$

dengan:

FK : nilai faktor koreksi

JRRB : jumlah rasio rata-rata bulanan

Indeks musim penangkapan (IMP) dapat dihitung menggunakan rumus:

$\mathrm{IMPi}=\mathrm{RRBi} \times \mathrm{FK}$

Dimana:

IMPi : Indeks musim penangkapan bulan ke-i

$\mathrm{RRBi}$ : rasio rata-rata bulanan

FK : nilai faktor koreksi

i $\quad: 1,2, \ldots ., 12$

Musim penangkapan ikan dapat digolongkan dalam dua kategori berdasarkan nilai indeks musim penangkapan (IMP) yaitu musim ikan dan tidak musim ikan (Tabel 1).

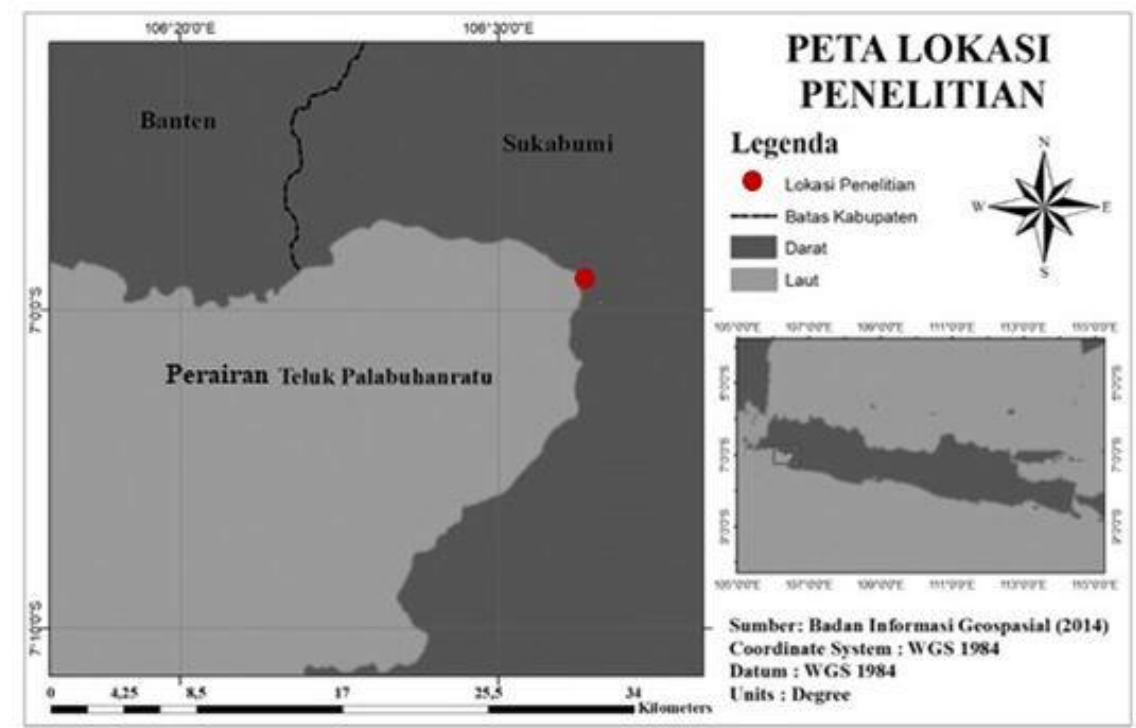

Gambar 1 Lokasi penelitian PPN Palabuhanratu 
Tabel 1 Kategori Musim Penangkapan

\begin{tabular}{cc}
\hline Nilai IMP & Kategori Musim \\
\hline$\geq 100 \%$ & Musim ikan \\
$<100 \%$ & Tidak musim ikan \\
\hline
\end{tabular}

\section{HASIL}

\section{Produksi lkan Cakalang dan Tongkol di PPN Palabuhanratu}

Ikan cakalang di Perairan Palabuhanratu ditangkap dengan menggunakan alat tangkap longline dan pancing tonda. Sementara itu, untuk ikan tongkol ditangkap dengan menggunakan alat tangkap payang, purse seine, pancing ulur, bagan, jaring rampus dan gillnet. Pada Tabel 2 terlihat jumlah alat tangkap digunakan oleh nelayan di PPN Palabuhanratu untuk menangkap ikan cakalang dan tongkol pada periode 20152019.

Produksi bulanan ikan cakalang dan tongkol yang didaratkan di PPN Palabuhanratu seperti terlihat pada Tabel 3. Produksi berkisar antara 1-129 ton/bulan untuk ikan cakalang, dan 0-87 ton/bulan untuk ikan tongkol. Produksi ikan cakalang dan tongkol menurun tajam pada tahun 2016 jika dibandingkan tahun 2015 yaitu masing-masing dari 285,19 ton menjadi 53.73 ton, dan dari 50,98 ton menjadi 7,04 ton atau menurun $81 \%$ dan $86 \%$. Hal ini diduga terkait dengan kebijakan moratorium kapal perikanan dan transhipment. Produksi ikan cakalang dan tongkol kembali meningkat pada tahun 2017 hingga 2019.

\section{Upaya Penangkapan dan Catch per Unit Effort}

Tabel 4 mendeskripsikan upaya penangkapan standar (trip) yang sudah distan- darisasi untuk penangkapan ikan cakalang, dengan alat tangkap standar adalah longline, dan alat tangkap standar untuk ikan tongkol yaitu payang. Upaya penangkapan untuk ikan cakalang terlihat terus mengalami penurunan pada periode tahun 2015-2019 yaitu dari 603 trip pada tahun 2015, menjadi 256 trip pada tahun 2019 atau rata-rata menurun sekitar $14 \%$ per tahun. Sementara itu, upaya penangkapan untuk ikan tongkol terlihat meningkat pada periode tahun 2015-2019 yaitu dari 1.795 trip pada tahun 2015 menjadi 2.740 trip pada tahun 2019 atau meningkat rata-rata $13 \%$ per tahun.

Hasil perhitungan CPUE berdasarkan data tahun 2015-2019 diperoleh nilai CPUE alat penangkap ikan cakalang terendah berada di tahun 2016 yaitu sekitar 0,009 ton per trip dan tertinggi pada tahun 2017 yaitu sekitar 3,068 ton per trip (Gambar 2). Terlihat bahwa berkurangnya upaya penangkapan ikan cakalang pada tahun 2016 mengindikasikan adanya pemulihan terhadap sumber daya ikan cakalang yang dampaknya terlihat pada meningkatnya CPUE pada tahun 2017.

Hasil perhitungan CPUE untuk alat penangkapan ikan tongkol terendah juga terjadi pada tahun 2016, selanjutnya meningkat pada tahun berikutnya dan mencapai tertinggi pada tahun 2019 (Gambar 3). Nilai CPUE alat penangkap ikan tongkol berkisar antara 0,021-0,266 ton per trip.

Tabel 2 Jumlah alat tangkap yang menangkap ikan cakalang dan tongkol di PPN Palabuhanratu periode tahun 2015-2019

\begin{tabular}{ccccccccc}
\hline \multirow{2}{*}{ Tahun } & Longline & $\begin{array}{c}\text { Pancing } \\
\text { tonda }\end{array}$ & Payang & Rampus & Bagan & $\begin{array}{c}\text { Pancing } \\
\text { ulur }\end{array}$ & $\begin{array}{c}\text { Purse } \\
\text { seine }\end{array}$ & Gillnet \\
\hline 2015 & 28 & 68 & 43 & 24 & 17 & 59 & 4 & 5 \\
2016 & 25 & 46 & 28 & 18 & 13 & 63 & 0 & 2 \\
2017 & 22 & 59 & 37 & 24 & 13 & 89 & 0 & 0 \\
2018 & 11 & 49 & 41 & 27 & 13 & 56 & 0 & 0 \\
2019 & 17 & 38 & 44 & 33 & 17 & 56 & 0 & 0 \\
\hline
\end{tabular}

Sumber: Statistik Perikanan PPN Palabuhanratu (data diolah) 
Tabel 3 Rata-rata hasil tangkapan ikan cakalang dan tongkol per bulan di PPN Palabuhanratu tahun 2015-2019

\begin{tabular}{|c|c|c|c|c|c|c|c|c|c|c|}
\hline \multirow{3}{*}{ Bulan } & \multicolumn{10}{|c|}{ Hasil tangkapan (Ton) } \\
\hline & \multicolumn{2}{|c|}{2015} & \multicolumn{2}{|c|}{2016} & \multicolumn{2}{|c|}{2017} & \multicolumn{2}{|c|}{2018} & \multicolumn{2}{|c|}{2019} \\
\hline & Cakalang & Tongkol & Cakalang & Tongkol & Cakalang & Tongkol & Cakalang & Tongkol & Cakalang & Tongkol \\
\hline Januari & 1,86 & 0,33 & 2,29 & 0,00 & 5,94 & 0,10 & 1,03 & 0,27 & 7,92 & 0,13 \\
\hline Februari & 2,44 & 0,09 & 1,76 & 0,15 & 6,01 & 0,31 & 5,72 & 0,00 & 19,91 & 0,10 \\
\hline Maret & 5,20 & 0,22 & 5,30 & 0,14 & 10,72 & 1,74 & 16,89 & 0,35 & 18,02 & 0,57 \\
\hline April & 8,39 & 0,04 & 8,80 & 0,01 & 15,21 & 0,67 & 10,47 & 0,11 & 24,73 & 1,18 \\
\hline Mei & 25,06 & 0,12 & 5,96 & 0,88 & 15,56 & 3,21 & 13,59 & 2,69 & 19,73 & 2,88 \\
\hline Juni & 128,57 & 0,23 & 4,62 & 0,10 & 14,51 & 1,22 & 9,81 & 1,71 & 19,79 & 35,51 \\
\hline Juli & 9,76 & 22,12 & 3,30 & 0,46 & 36,18 & 2,62 & 16,09 & 8,64 & 62,95 & 87,29 \\
\hline Agustus & 24,36 & 17,40 & 4,16 & 0,82 & 29,23 & 24,21 & 28,88 & 5,37 & 54,41 & 18,72 \\
\hline September & 55,63 & 4,74 & 2,30 & 2,24 & 21,27 & 14,48 & 43,83 & 22,52 & 22,31 & 0,00 \\
\hline Oktober & 14,60 & 3,42 & 3,08 & 1,31 & 14,80 & 12,97 & 32,67 & 0,09 & 25,98 & 10,71 \\
\hline November & 5,47 & 0,92 & 6,01 & 0,92 & 4,71 & 0,06 & 30,57 & 0,00 & 29,14 & 6,38 \\
\hline Desember & 3,86 & 1,35 & 6,16 & 0,02 & 2,25 & 0,10 & 16,03 & 0,02 & 13,11 & 8,86 \\
\hline Total & 285,19 & 50,98 & 53,73 & 7,04 & 176,40 & 61,67 & 225,58 & 41,76 & 318,00 & 172,31 \\
\hline
\end{tabular}

Tabel 4 Rata-rata trip penangkapan ikan cakalang dan tongkol per bulan di PPN Palabuhanratu tahun 2015-2019

\begin{tabular}{|c|c|c|c|c|c|c|c|c|c|c|}
\hline \multirow{3}{*}{ Bulan } & \multicolumn{10}{|c|}{ Trip } \\
\hline & \multicolumn{3}{|c|}{2015} & \multicolumn{2}{|l|}{2016} & \multicolumn{2}{|l|}{2017} & \multicolumn{2}{|l|}{2018} & \multirow{2}{*}{$\begin{array}{r}2019 \\
\text { Tongkol }\end{array}$} \\
\hline & Cakalang & Tongkol & Cakalang & Tongkol & Cakalang & Tongkol & Cakalang & Tongkol & Cakalang & \\
\hline Januari & 37 & 64 & 26 & 230 & 33 & 132 & 13 & 118 & 12 & 144 \\
\hline Februari & 29 & 99 & 16 & 182 & 23 & 117 & 19 & 103 & 11 & 187 \\
\hline Maret & 33 & 121 & 27 & 203 & 35 & 131 & 31 & 118 & 18 & 144 \\
\hline April & 56 & 111 & 35 & 157 & 46 & 144 & 37 & 121 & 18 & 127 \\
\hline Mei & 73 & 138 & 37 & 177 & 49 & 146 & 37 & 151 & 33 & 145 \\
\hline Juni & 68 & 132 & 38 & 125 & 42 & 170 & 34 & 120 & 24 & 190 \\
\hline Juli & 59 & 161 & 19 & 109 & 50 & 135 & 40 & 174 & 37 & 325 \\
\hline Agustus & 63 & 203 & 29 & 138 & 49 & 194 & 40 & 189 & 36 & 291 \\
\hline September & 71 & 175 & 22 & 146 & 46 & 168 & 34 & 235 & 21 & 417 \\
\hline Oktober & 54 & 238 & 25 & 148 & 44 & 210 & 32 & 198 & 12 & 263 \\
\hline November & 36 & 172 & 25 & 138 & 32 & 134 & 23 & 255 & 18 & 238 \\
\hline Desember & 28 & 184 & 29 & 112 & 20 & 154 & 21 & 190 & 17 & 269 \\
\hline Total & 603 & 1.795 & 326 & 1.865 & 466 & 1.835 & 358 & 1.973 & 256 & 2.740 \\
\hline
\end{tabular}

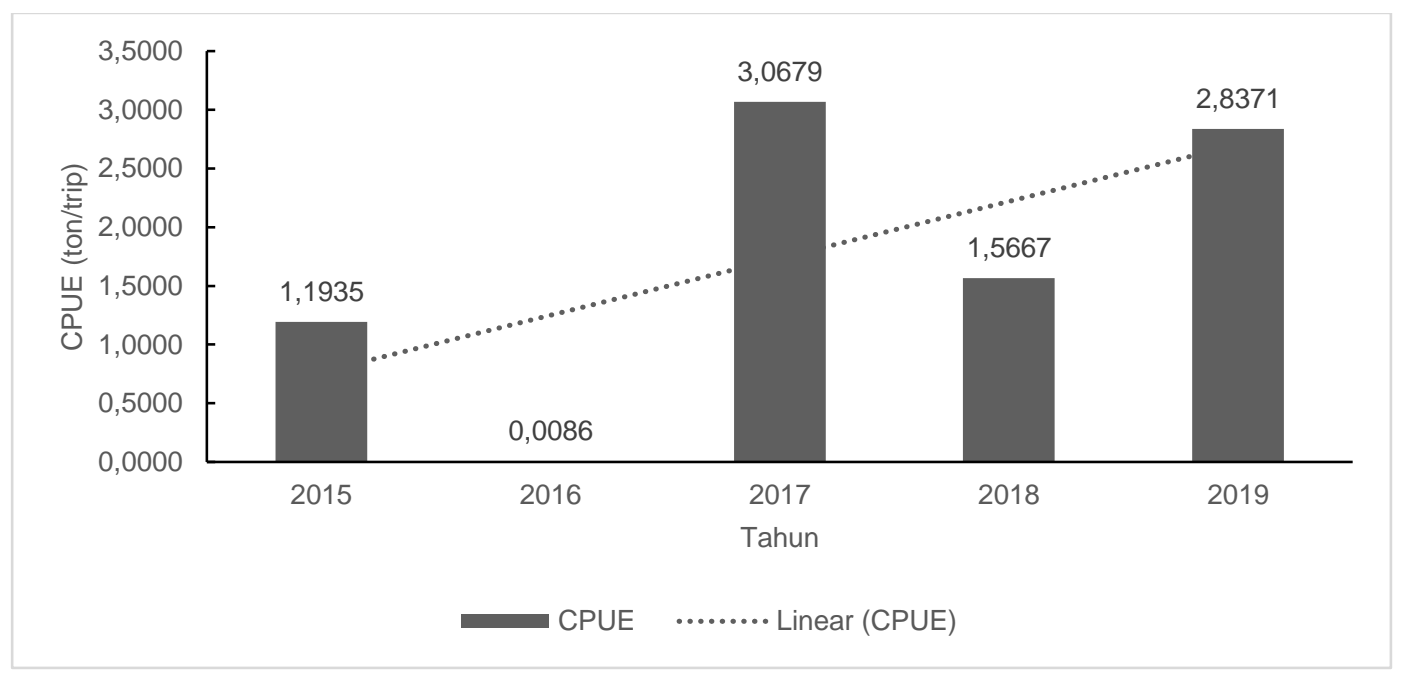

Gambar 2 CPUE alat penangkap ikan cakalang Palabuhanratu tahun 2015-2019 


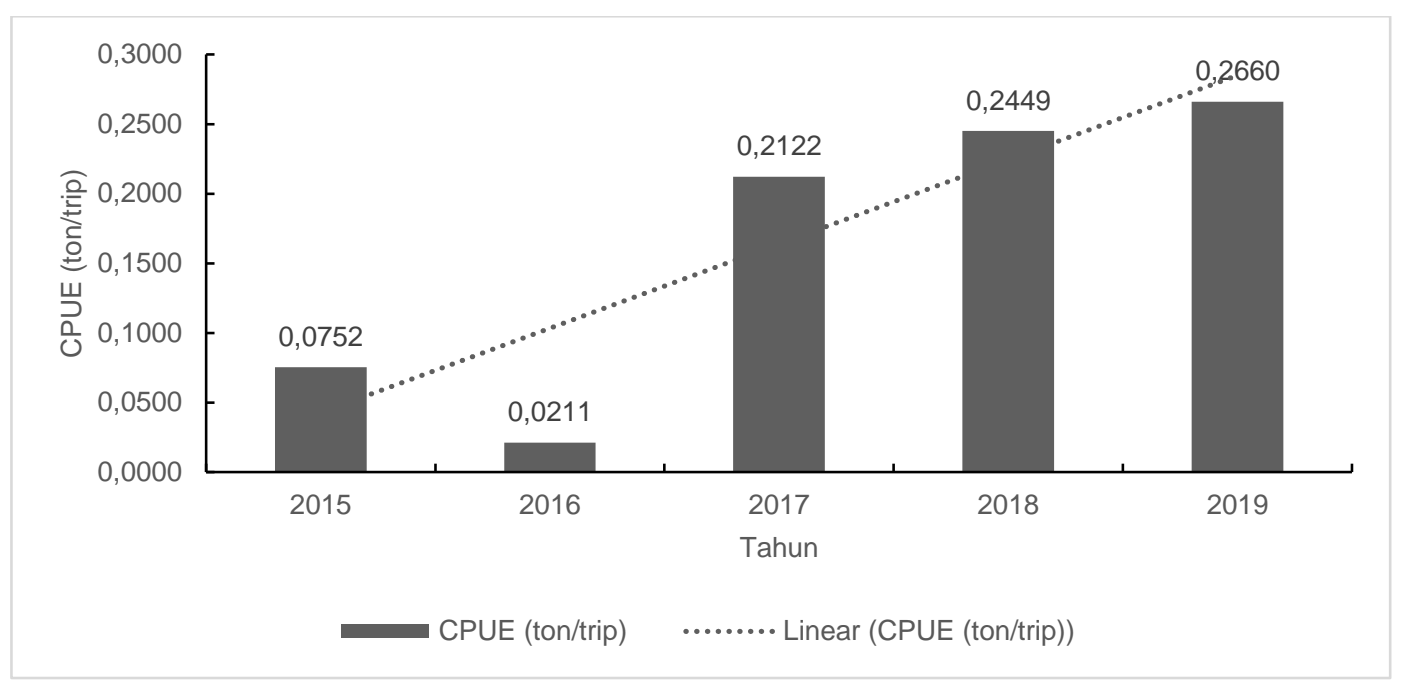

Gambar 3 CPUE alat penangkap ikan tongkol Palabuhanratu tahun 2015-2019

\section{Musim Penangkapan Cakalang dan Tongkol}

Berdasarkan hasil wawancara dengan nelayan, ikan cakalang dan tongkol yang didaratkan oleh nelayan di PPN Palabuhanratu memiliki daerah penangkapan ikan di sekitar Perairan Palabuhanratu. Kegiatan penangkapan ikan dilakukan hampir sepanjang tahun, namun demikian hasil tangkapannya berfluktuasi tergantung musim. Hasil analisis berbasis data produksi bulanan selama 5 tahun (2015-2019) menunjukkan bahwa IMP ikan cakalang di Perairan Palabuhanratu berfluktuasi setiap bulannya. Pada Gambar 4 terlihat bahwa berdasarkan data periode 2015-2019 nilai IMP ikan cakalang tertinggi terjadi pada sekitar bulan Agustus, serta nilai IMP ikan cakalang terendah pada bulan Desember-Januari dan April-Mei. Hasil tangkapan ikan cakalang pada tahun 2018 menunjukkan fluktuasi musim yang tidak terlalu besar.

Hasil analisis berbasis data produksi bulanan selama 5 tahun (2015-2019) untuk ikan tongkol seperti terlihat pada Gambar 5. Fluktuasi musiman ikan tongkol pada periode tahun tersebut tidak begitu tinggi. Hal ini terlihat dari fluktuasi nilai IMP yang tidak begitu besar. Nilai IMP cukup tinggi terjadi pada tahun 2015 dan tahun 2016, yaitu mencapai nilai sekitar $500 \%$ dan $700 \%$. Hal ini diduga adanya aktivitas penangkapan yang tinggi dari unit penangkapan ikan skala kecil di perairan ini, sebagai dampak dari tidak melautnya kapal-kapal longline di Perairan Palabuhanratu pada sekitar tahun tersebut.

Selanjutnya, pola musim penangkapan ikan cakalang dan tongkol dari periode 5 tahun tersebut secara rataan dibuat menjadi pola umum musim penangkapan ikan dalam satu tahun, dengan kisaran IMP untuk ikan cakalang antara 35,71\%-168,03\% dan ikan tongkol antara $24,37 \%-192,97 \%$ (Tabel 5). Nilai IMP lebih dari 100\% menunjukkan musim penangkapan ikan, sedangkan nilai IMP kurang dari 100\% menunjukkan bukan musim ikan.

Nilai rata-rata IMP yang dihasilkan seperti tersebut di atas menjadi suatu gambaran dari musim penangkapan ikan cakalang dan tongkol di Perairan Palabuhanratu, yaitu seperti dapat dilihat pada Gambar 5. Nilai IMP ikan cakalang di Perairan Palabuhanratu yang lebih dari 100\% diperoleh di bulan Maret dan Juli sampai dengan November. Hal ini mengindikasikan bahwa musim penangkapan ikan cakalang terjadi pada bulan-bulan tersebut. Sementara pada bulan lainnya nilai IMP ikan cakalang kurang dari $100 \%$, dengan nilai IMP ikan cakalang terendah adalah bulan Januari. Berdasarkan Gambar 6, nilai IMP ikan tongkol lebih dari $100 \%$ diperoleh di bulan Mei sampai dengan November. Hal ini mengindikasikan bahwa musim penangkapan ikan tongkol terjadi pada bulan-bulan tersebut. Sementara pada bulan lainnya nilai IMP ikan tongkol kurang dari $100 \%$, dengan nilai IMP ikan tongkol terendah adalah bulan Februari. 


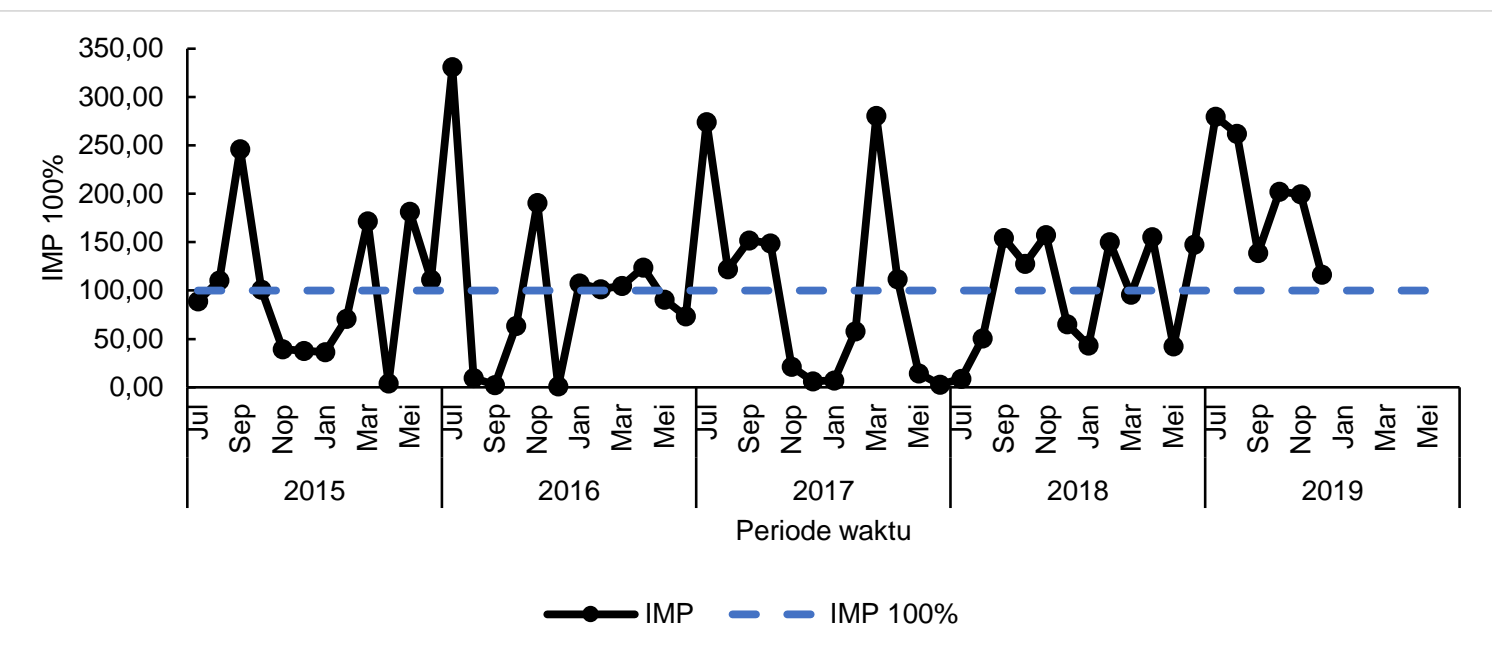

Gambar 4 Pola musim penangkapan ikan cakalang di Perairan Palabuhanratu pada periode tahun 2015-2019

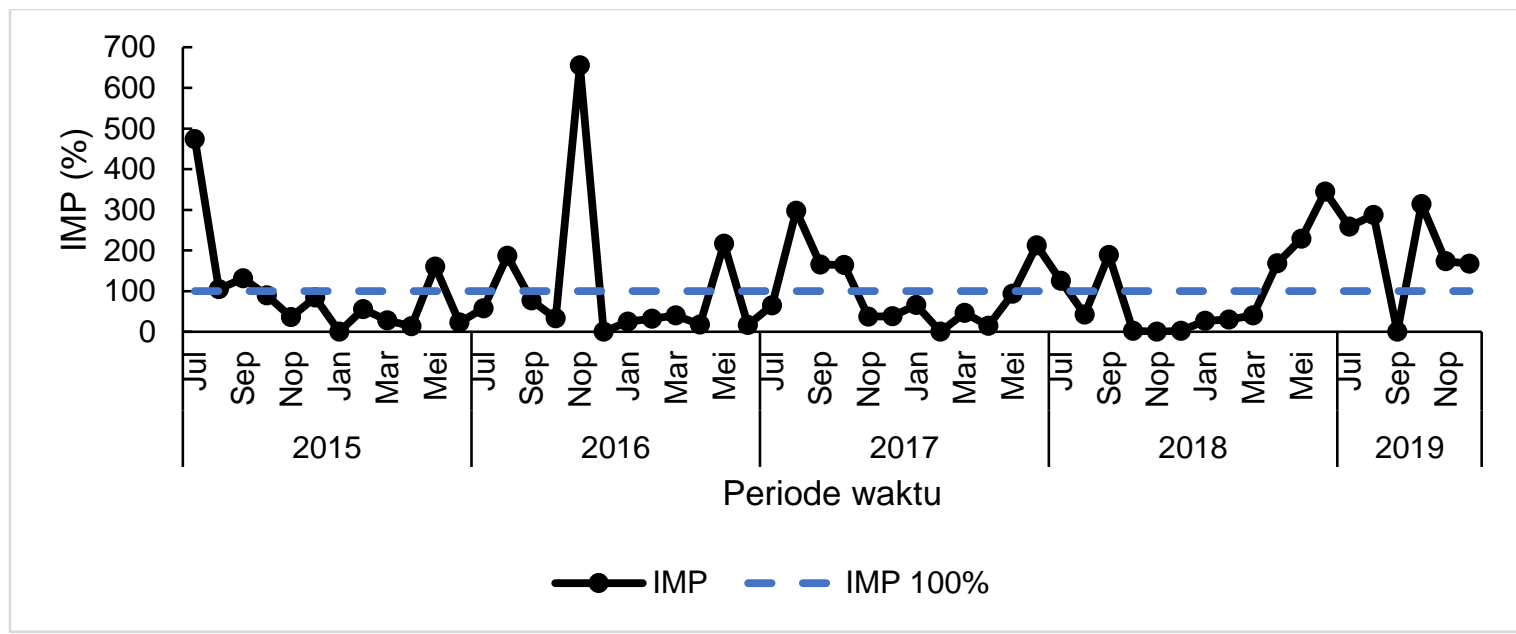

Gambar 5 Pola musim penangkapan ikan tongkol di Perairan Palabuhanratu pada periode tahun 2015-2019

Tabel 5 IMP ikan cakalang dan tongkol di Perairan Palabuhanratu pada tahun 2015-2019

\begin{tabular}{ccc}
\hline Bulan & Nilai IMP ikan cakalang (\%) & Nilai IMP ikan tongkol (\%) \\
\hline Jan & 35,71 & 24,98 \\
Feb & 85,95 & 24,37 \\
Mar & 135,32 & 32,76 \\
Apr & 91,79 & 58,94 \\
Mei & 58,46 & 123,96 \\
Jun & 75,68 & 150,53 \\
Jul & 168,02 & 192,97 \\
Ags & 105,01 & 167,74 \\
Sep & 146,07 & 125,90 \\
Okt & 131,61 & 107,43 \\
Nop & 119,06 & 138,45 \\
Des & 47,33 & 51,96 \\
\hline
\end{tabular}




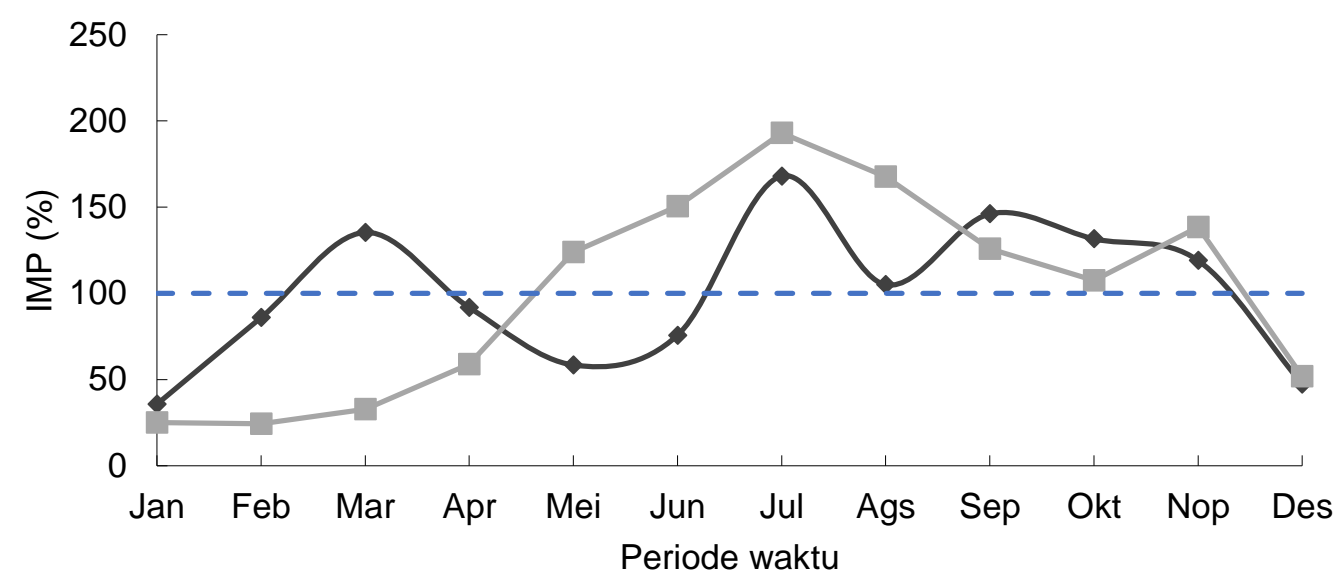

$\longrightarrow$ Nilai IMP Cakalang (\%) _ Nilai IMP Tongkol (\%) - - - IMP 100\%

Gambar 6 IMP ikan cakalang dan tongkol di Perairan Palabuhanratu tahun 2015-2019

\section{PEMBAHASAN}

Pada Tabel 3 terlihat bahwa produksi ikan cakalang dan tongkol yang didaratkan di PPN Palabuhanratu menurun tajam pada tahun 2016, dan mulai meningkat kembali pada tahun 2017, 2018 dan 2019. Penurunan produksi ikan cakalang dan tongkol tersebut diduga disebabkan oleh diberlakukannya kebijakan pemerintah terkait moratorium izin usaha perikanan tangkap dan pelarangan transhipment. Hal ini seperti yang terjadi pada ikan tuna yang didaratkan di Pelabuhan Benoa Bali, dimana produksi ikan tuna yang merupakan hasil tangkapan longline menurun pada tahun 2016-2017 sebagai dampak dari kebijakan pemerintah (Imron et al. 2021).

Hal berbeda terjadi pada upaya penangkapan ikan cakalang dan tongkol di Perairan Palabuhanratu, dimana upaya penangkapan ikan cakalang pada periode tahun 2015-2019 terlihat menurun, namun untuk upaya penangkapan ikan tongkol terlihat meningkat. Hal ini dapat diduga bahwa salah satu unit penangkapan ikan yang digunakan untuk menangkap ikan cakalang, yaitu longline, tidak melakukan operasi penangkapan ikan sebagai dampak dari kebijakan pemerintah seperti tersebut di atas. Pada sisi lain, unit penangkapan ikan tongkol yang utamanya menggunakan unit penangkapan ikan skala kecil, meningkat aktivitasnya.

Hasil perhitungan CPUE berdasarkan data tahun 2015-2019 diperoleh nilai CPUE alat penangkap ikan cakalang terendah berada di tahun 2016 yaitu sekitar 0,0086 ton per trip dan tertinggi pada tahun 2017 yaitu sekitar 3,0679 ton per trip. Kondisi yang sama terjadi pada ikan tongkol, dengan CPUE alat penangkap ikan tongkol terendah juga terjadi pada tahun 2016, selanjutnya meningkat pada tahun berikutnya dan mencapai tertinggi pada tahun 2019. Terlihat bahwa berkurangnya upaya penangkapan ikan cakalang dan tongkol pada tahun 2016 mengindikasikan adanya pemulihan terhadap sumber daya ikan cakalang yang dampaknya terlihat pada meningkatnya CPUE tahun 2017. Dollu \& Muksin (2019) menyatakan bahwa nilai CPUE menggambarkan tingkat produktivitas upaya, semakin tinggi nilai CPUE menunjukkan tingkat produktivitas alat tangkap yang digunakan juga semakin tinggi. Penurunan CPUE merupakan salah satu indikator bahwa sumber daya ikan telah ditangkap secara berlebih. Mengacu pada nilai CPUE dari hasil penelitian ini, maka dapat dinyatakan bahwa sumber daya ikan cakalang dan tongkol di Perairan Palabuhanratu masih dapat ditingkatkan pemanfaatannya.

Musim penangkapan ikan sering dikaitkan dengan kelimpahan ikan yang ditangkap selama periode tertentu (biasanya bulan). Upaya penangkapan ikan merupakan faktor utama untuk menentukan kelimpahan ikan. Oleh karena itu sebagian besar perhitungan musim penangkapan mengguna-kan CPUE sebagai dasar analisis (Setyadji et al.2018).

Ikan cakalang dan tongkol yang didaratkan oleh nelayan di PPN Palabuhanratu memiliki daerah penangkapan ikan di sekitar 
Perairan Palabuhanratu. Kegiatan penangkapan ikan dilakukan hampir sepanjang tahun, namun demikian hasil tangkapannya berfluktuasi tergantung musim. Hasil analisis berbasis data produksi bulanan selama 5 tahun (2015-2019) menunjukkan bahwa IMP ikan cakalang dan tongkol di Perairan Palabuhanratu berfluktuasi setiap bulan dan setiap tahun. Nilai IMP ini dipengaruhi oleh berbagai faktor yaitu terkait dengan upaya penangkapan ikan yang dilakukan oleh nelayan dan kondisi perairan yang mempengaruhi terhadap keberhasilan dari penangkapan ikan yang dilakukan.

Nilai rata-rata IMP yang dihasilkan menjadi suatu gambaran dari musim penangkapan ikan cakalang dan tongkol di Perairan Palabuhanratu. Hasil dari nilai rata-rata IMP ikan cakalang menunjukkan bahwa musim penangkapan ikan cakalang terjadi pada bulan Maret, Juli sampai dengan November. Hasil penelitian ini menujukkan hal yang tidak jauh berbeda dengan penelitian Nurdin \& Panggabean (2017) dan Kurniawan (2015). Nurdin \& Panggabean (2017) menyatakan bahwa musim penangkapan ikan cakalang di Palabuhanratu terjadi pada bulan September sampai Januari, sementara Kurniawan (2015) menyatakan musim penangkapan ikan cakalang di Palabuhanratu terjadi pada bulan Agustus sampai Desember. Hasil penelitian ini menunjukkan bahwa musim penangkapan ikan cakalang di Perairan Palabuhanratu bertepatan dengan musim timur. Hal ini sesuai dengan penelitian Rahman et al. (2019) yang menyatakan bahwa musim penangkapan ikan cakalang di Perairan Selatan Jawa Barat terjadi pada musim timur.

Sementara itu, dari hasil penelitian ini juga menunjukkan bahwa musim penangkapan ikan tongkol terjadi pada bulan Mei sampai dengan November. Hal ini tidak jauh berbeda dengan penelitian yang dilakukan oleh Ekaputra et al. (2019) yang menyatakan bahwa rata-rata hasil tangkapan ikan tongkol tertinggi terjadi pada musim peralihan 2 yaitu, pada bulan September-November dengan memiliki rata-rata hasil tangkapannya ikan tongkol sebesar 106,3 ton. Kuswanto et al. (2017) menyatakan bahwa kondisi perairan merupakan salah satu faktor yang berpengaruh pada produksi perikanan. Musim barat merupakan musim dengan produksi ikan tongkol paling kecil diantara musim yang lain. Faktor cuaca menjadi salah satu yang berpengaruh terhadap produksi ikan tongkol di Teluk Lampung (Kuswantoet al. 2017).
Curah hujan yang tinggi disertai angin yang kencang menjadi alasan nelayan untuk tidak melaut karena risiko yang cukup tinggi.

Penelitian ini memberikan hasil bahwa keberadaan ikan cakalang dan tongkol di Perairan Pelabuhanratu tidak sepanjang tahun, melainkan ada bulan-bulan tertentu yang menjadi puncak musim penangkapan. Untuk meningkatkan efektivitasnya, maka kegiatan operasi penangkapan ikan yang dilakukan oleh nelayan dapat dilakukan pada bulan-bulan tersebut.

\section{KESIMPULAN}

Hasil penelitian menunjukkan bahwa nilai CPUE alat penangkap ikan cakalang dan tongkol di PPN Palabuhanratu berfluktuasi cenderung meningkat. CPUE alat penangkap ikan cakalang memiliki nilai dari 0,01 ton per trip pada tahun 2015 menjadi 2,84 ton per trip pada tahun 2019 dan mencapai tertinggi pada tahun 2017 yaitu sekitar 3,07 ton per trip. Nilai CPUE alat penangkap ikan tongkol cenderung meningkat yaitu dari 0,02 ton per trip tahun 2015 menjadi 0,27 ton per trip pada tahun 2019. Musim penangkapan ikan cakalang di Perairan Palabuhanratu terjadi pada bulan Maret, dan Juli sampai dengan November, sedangkan musim penangkapan ikan tongkol di Perairan Palabuhanratu terjadi pada bulan Mei sampai dengan November.

\section{SARAN}

Musim penangkapan ikan cakalang dan tongkol di Perairan Palabuhanratu dari hasil penelitian ini diketahui bersamaan dengan musim timur. Hasil ini dapat diintegrasikan dengan penelitian terkait dengan kondisi oseanografis perairan khususnya suhu permukaan laut dan kandungan khorofil-a untuk dapat memetakan daerah penangkapan potensial ikan cakalang dan tongkol di perairan tersebut. Kegiatan operasi penangkapan ikan oleh nelayan yang ditujukan untuk menangkap ikan cakalang dan tongkol perlu disesuaikan dengan keberadaan musim penangkapan ikan ini.

\section{UCAPAN TERIMA KASIH}

Penulis mengucapkan terima kasih kepada Kementerian Riset, Teknologi, dan Pendidikan Tinggi atas pendanaan penelitian dengan Skema Penelitian Dasar Unggulan 
Perguruan Tinggi. Terima kasih juga kami sampaikan kepada pengelola PPN Palabuhanratu atas kerjasama dalam penyediaan data untuk kebutuhan penelitian.

\section{DAFTAR PUSTAKA}

Ahmad Y. 2015. Aplikasi Z-Transformation untuk Pendugaan Musim Beberapa Jenis Ikan. Jurnal Agroscience. 5(1): 15-23.

Dollu EA, Muksin R. 2019. Sustainable Catching Analysis of Cakalang (Katsuwonus pelamis) in Pantar Strait Waters, Alor Regency Nusa Tenggara Province. International Journal of Fisheries and Aquatic Studies. 7(2): 282-286.

Ekaputra M, Hamdani H, Bangkit I, Apriliani IM. 2019. Penentuan Daerah Penangkapan Potensial Ikan Tongkol (Euthynnus sp.) Berdasarkan Citra Satelit Klorofil-a di Palabuhanratu, Jawa Barat. Albacore. 3(2): 169-178.

Gulland JA. 1982. Manual of methods for stock assessment. FAO Rome.

Imron M, Tawaqal MI, Yusfiandayani R. 2021. Fishing Ground and Tuna Productivity by Tuna Longline Based on Benoa Bay, Bali, Indonesia. Biodiversitas. 22(2): 961-968.

[IOTC] Indian Ocean Tuna Commission. 2016. Report of the 18th Session of the IOTC Working Party on Tropical Tunas. Seychelles, 5-10 November 2016. IOTC-2016-WPTT18-R[E]. 126 pp.

Ishak AA, Alimina N, Arami H. 2020. Musim Penangkapan Ikan Tongkol (Euthynnus affinis) yang didaratkan di Kota Kendar. Jurnal Manajemen Sumber Daya Perairan. 5(3): 220-226.

Kantun W, Darris L, Arsana WS. 2018. Komposisi Jenis dan Ukuran Ikan yang Ditangkap pada Rumpon dengan Pancing Ulur di Selat Makassar. Marine Fisheries. 9(2): 157-167.

Kurniawan W. 2015. Musim Penangkapan Ikan Cakalang di Perairan Selatan Jawa Barat dan Kaitannya dengan
Parameter Oseanografi. Oseana. 40(4): 53-60.

Kuswanto TD, Syamsuddin ML, Sunarto. 2017. Hubungan Suhu Permukaan Laut dan Klorofil-a terhadap Hasil Tangkapan Ikan Tongkol di Teluk Lampung. Jurnal Perikanan dan Kelautan. 8(2): 90-102.

Mujib Z, Boesono H, Fitri ADP. 2013. Pemetaan Sebaran Ikan Tongkol (Euthynnus sp.) dengan Data Klorofil- $\alpha$ Citra Modis pada Alat Tangkap Payang (Danish-Seine) di Perairan Teluk Palabuhanratu, Sukabumi, Jawa Barat. Journal of Fisheries Resources Utilization Management and Technology. 2(2): 150-160.

Nurani TW, Wahyuningrum PI, Wisudo $\mathrm{SH}$, Arhatin RE, Komarudin D. 2015. Catch of Tuna Fish on Trolling Fishing in Indian Ocean Waters, Southern Coast of East Java Related to Sea Surface Temperature Variability. Malays. Appl. Biol. 44(3):25-28.

Nurani TW, Wisudo SH, Wahyuningrum PI, Arhatin RE, Gigentika S. 2016. The Dynamic of Fishing Season and Tuna Fishing in the Indian Ocean Waters (FMA) 573. International Journal of Development Research. 8(6): 82888294.

Nurdin E, Panggabean AS. 2017. Musim Penangkapan dan Struktur Ukuran Cakalang (Katsuwonus pelamis Linnaeus, 1758) di Sektor Rumpon di Perairan Palabuhanratu. Jurnal Penelitian Perikanan Indonesia. 23(4): 299-308.

Rahman MA, Laksmini M, Agung UK, Sunarto. 2019. Pengaruh Musim terhadap Kondisi Oseanografi dalam Penentuan Daerah Penangkapan Ikan Cakalang (Katsuwonus pelamis) di Perairan Selatan Jawa Barat. Jurnal Perikanan dan Kelautan. 10(1): 92-102.

Safruddin, Zainuddin M, dan Rani C. 2014. Prediksi Daerah Potensial Penangkapan Ikan Pelagis Besar di Perairan Kabupaten Mamuju. Jurnal Ipteks PSP. 1(2): 185-195. 
Setyadji B, Pranowo WS, Amri K. 2018. SeaAir Impacts on Fishing Season of Hand Line Skip Jack Tuna Katsuwonus pelamis (Linnaeus, 1758) in Southern Pacitan Waters, East Java-Indonesia. Omni-Akuatika. 14(1):1-10.

Simbolon D. 2009. Eksplorasi Daerah Penangkapan Ikan Cakalang Melalui Analisis Suhu Permukaan Laut dan Hasil Tangkapan di Perairan Teluk Palabuhanratu. Jurnal Mangrove dan Pesisir. 10(1): 42-49.

Situmorang DM, Agustriani F, Fauziyah. 2018. Analisis Penentuan Musim Penangkapan Ikan Tenggiri (Scomberomorus sp.) yang Didaratkan di PPN Sungailiat, Bangka. Maspari Journal. 10(1):81-88.

Wangi DAP, Sunardi, Rahman MA. 2019. Pendugaan Daerah Potensi Penangkapan Ikan Cakalang (Katsuwonus Pelamis) Berdasarkan Parameter Oseanografi di PerairanSelat Makassar. Journal of Fisheries and Marine Research. 3(1):86-92.

Waileruny W, Wiyono ES, Wisudo SH, Purbayanto A, Nurani TW. 2014. BioEconomics Analysis of Skipjack (Katsuwonus pelamis) Fishery on Banda Sea-Maluku Province.
International Journal of Science: Basic and Applied Research (IJSBAR). 14(1):239-251.

Wiryawan $\mathrm{B}$, Loneragan $\mathrm{N}$, Mardhiah $\mathrm{U}$, Kleinertz S, Wahyuningrum PI, Pingkan J, Wildan, Timur PS, Duggan D, Yulianto J. 2020. Catch per Unit Effort Dynamic of Yellowfin Tuna Related to Sea Surface Temperature and Chlorophyll in Southern Indonesia. Fishes. 5(28):1-16.

Wiyono ES, Yamada S, Tanaka E, Arimoto T, Kitakado. 2006. Dynamics of Fishing Gear Allocation by Fishers in Smallscale coastal fisheries of Palabuhanratu Bay, Indonesia. Fisheries Management and Ecology. 13(3):185-195.

Zainuddin M, Safruddin, Farhum SA, Nelwan $A$, Selamat MB, Hidayat S, Sudirman. 2015. Characteristics of Skipjack Tuna Potential Fishing Ground in the Bone BayFlores Sea Based on Sea Surface Temperature and Chlorophyll Data for the Period of January-June 2014. Jurnal IPTEKS. 2(3): 228-237.

Zulkhasyni. 2015. Pengaruh Suhu Permukaan Laut Terhadap Hasil Tangkapan Ikan Cakalang di Perairan Kota Bengkulu. Jurnal Agroqua. 13(2): 68-73. 